\title{
Statistical Study of the Effects of the Composition on the Oxidation Resistance of Ni-Based Superalloys
}

\author{
Si-Jun Park, ${ }^{1}$ Seong-Moon Seo, ${ }^{2}$ Young-Soo Yoo, ${ }^{2}$ Hi-Won Jeong, ${ }^{2}$ and HeeJin Jang ${ }^{3}$ \\ ${ }^{1}$ Department of Energy Convergence, Chosun University, 309 Pilmundaero, Dong-gu, Gwangju 501-759, Republic of Korea \\ ${ }^{2}$ High Temperature Materials Group, Korea Institute of Materials Science, 797 Changwondaero, Seongsan-gu, \\ Changwon 642-831, Republic of Korea \\ ${ }^{3}$ Department of Materials Science and Engineering, Chosun University, 309 Pilmundaero, Dong-gu, \\ Gwangju 501-759, Republic of Korea \\ Correspondence should be addressed to HeeJin Jang; heejin@chosun.ac.kr
}

Received 17 April 2015; Accepted 7 June 2015

Academic Editor: Jing Zhang

Copyright (C) 2015 Si-Jun Park et al. This is an open access article distributed under the Creative Commons Attribution License, which permits unrestricted use, distribution, and reproduction in any medium, provided the original work is properly cited.

The effects of alloying elements ( $\mathrm{Co}, \mathrm{Cr}, \mathrm{Mo}, \mathrm{W}, \mathrm{Al}, \mathrm{Ti}$, and $\mathrm{Ta}$ ) on the oxidation resistance of Ni-based superalloys are studied using the Response Surface Methodology (RSM). The statistical analysis showed that Al and Ta generally improve the oxidation resistance of the alloy, whereas $\mathrm{Ti}$ and Mo degrade the oxidation resistance. $\mathrm{Co}, \mathrm{Cr}$, and $\mathrm{W}$ did not alter oxidation rate significantly when examined by the mass gain averaged for all model alloys. However, it is remarkable that the degree of the effects of alloying elements varied with the concentration of other elements. Further, the effect of each element was sometimes found to be reversed for alloy groups specified by the concentration of another element.

\section{Introduction}

Ni-based superalloys have excellent high resistance to oxidation and corrosion as well as remarkable mechanical properties at high temperatures. These alloys are used essentially for gas turbine blades of power plants, aerospace systems, heat exchangers, and chemical reactors. The durability of materials largely depends on the oxidation resistance in these systems. Ceramic coatings are widely used to protect the alloy surface from the high temperature gas, but extremely high resistance of alloy itself is still required to prevent sudden failure due to defect or degradation of coatings [1,2].

Therefore researchers have studied the oxidation behavior and tried to find ways to improve the oxidation resistance as well as the mechanical properties of superalloys. Ni-based superalloys contain $\mathrm{Co}, \mathrm{Cr}, \mathrm{Mo}$, and $\mathrm{W}$ for sold solution strengthening and $\mathrm{Al}, \mathrm{Ti}$, and $\mathrm{Ta}$ for precipitation strengthening, generally. $\mathrm{Cr}$ and $\mathrm{Al}$ are well known to improve the oxidation resistance because they form $\mathrm{Cr}_{2} \mathrm{O}_{3}$ or $\mathrm{Al}_{2} \mathrm{O}_{3}$, respectively, acting as protective barriers [3-5]. The beneficial effect of $\mathrm{Cr}_{2} \mathrm{O}_{3}$ is limited up to $871^{\circ} \mathrm{C}\left(1600^{\circ} \mathrm{F}\right)$ due to volatility and $\mathrm{Al}_{2} \mathrm{O}_{3}$ is responsible for the oxidation resistance at higher temperatures [6-9]. However, excessive alloying of $\mathrm{Cr}$ and $\mathrm{Al}$ in superalloys causes degradation of mechanical properties [8]. Mo and W can increase high temperature strength of the superalloys but they have been known to lower the oxidation resistance [10-14]. Nevertheless, some recent researches suggested that Mo facilitates growth of continuous $\mathrm{Cr}_{2} \mathrm{O}_{3}$ layer by lowering oxygen activity on the surface of $\mathrm{Ni}-\mathrm{Mo}-\mathrm{Cr}$ alloys [15] and $\mathrm{W}$ suppresses volatilization of $\mathrm{Cr}$ oxide from $\mathrm{Ni}$ $\mathrm{Cr}-\mathrm{W}$ alloys at a high temperature over $1100^{\circ} \mathrm{C}$ [16]. Ta was reported to increase oxidation resistance when its concentration is less than 1 at.\% by promoting rapid growth of $\mathrm{Al}_{2} \mathrm{O}_{3}$ layer but was found to reduce the oxidation resistance when the concentration is higher as 3 at.\% [17]. Park et al. [18] suggested that $\mathrm{Ta}$ exerts different effects on the oxidation resistance depending on the $\mathrm{Al}$ concentration in Ni-based superalloys.

The previous reports imply that the effects of alloying elements disagree with each other, due possibly to the alloy composition. The effects of other elements on the role of an element in oxidation should be considered as well. However 
it is impossible practically to examine the effects of each element under full combination of other elements concentration, because it requires huge number of experiments. Therefore, more systematic approach is necessary to elucidate the complicated effects of many alloying elements of superalloys. The DOE (Design of Experiments) can be a solution for this problem in that it provides an efficiently designed set of experiments. It is a statistical technique to design experimental parameters to analyze efficiently the relation between the independent variables, concentrations of alloying elements for an example, and the responses, oxidation rate for an example. The DOE is successfully used in screening and optimization of a process or a material $[2,19-23]$. The averaged effect of an alloying element over whole test range and also the interactions with other elements can be analyzed from a minimum number of experiments. We can predict the response value of untested point or seek a point which will give a specific response by statistical analysis. Another advantage of using DOE is that all the information is given quantitatively with corresponding probability. Thus we can compare the effects of alloying elements in quantity.

In this work, the effects of alloying elements (Co, Cr, $\mathrm{Mo}, \mathrm{W}, \mathrm{Al}, \mathrm{Ti}$, and $\mathrm{Ta}$ ) on the oxidation resistance of $\mathrm{Ni}$ based superalloys are studied by a DOE. The cyclic oxidation behavior of $\mathrm{Ni}-(0 \sim 15) \mathrm{Co}-(8 \sim 15) \mathrm{Cr}-(0 \sim 5) \mathrm{Mo}-(0 \sim 10) \mathrm{W}-(3 \sim$ 8) $\mathrm{Al}-(0 \sim 5) \mathrm{Ti}-(0 \sim 10) \mathrm{Ta}-0.1 \mathrm{C}-0.01 \mathrm{~B}$ alloys was examined and the results were discussed by statistical analysis on the weight changes as well as by the structure and the composition of oxide scales.

\section{Experimental Procedures}

The alloy composition was designed by Box-Behnken scheme of RSM (Response Surface Methodology). The Box-Behnken method is employed when high efficiency is required due to the large number of the factors, that is, independent variables, and the optimum response is not supposed to be found at the limit values of all factors. The range of alloy composition was $(0 \sim 15) \mathrm{Co}-(8 \sim 15) \mathrm{Cr}-(0 \sim 5) \mathrm{Mo}-(0 \sim 10) \mathrm{W}-(3 \sim 8) \mathrm{Al}-$ $(0 \sim 5) \mathrm{Ti}-(0 \sim 10) \mathrm{Ta}-0.1 \mathrm{C}-0.01 \mathrm{~B}$ and the list of alloys designed for the test in this study is shown in Table 1. The alloys were made in a vacuum arc melting furnace and cut into a coupon of $10 \mathrm{~mm}$ diameter and $3 \mathrm{~mm}$ height and finished by \#600 SiC paper.

Alumina crucibles of $20 \mathrm{~mm} \times 20 \mathrm{~mm} \times 15 \mathrm{~mm}(W \times D \times$ $H$ ) were used to contain the specimens during oxidation tests, in order to measure the weight of the specimens including the scales fallen with cycling. The crucibles were preoxidized at $1000^{\circ} \mathrm{C}$ for $100 \mathrm{~h}$ to ensure no weight change during experiments.

The specimens were put in the furnace at $400^{\circ} \mathrm{C}$ and the temperature was increased up to $850^{\circ} \mathrm{C}$ at the rate of $3.75^{\circ} \mathrm{C}$. After $15 \mathrm{~h}$, the furnace was cooled down slowly by waiting for $2 \mathrm{~h}$ with the power off and then with the door open for about $2 \mathrm{~h}$. The specimens were pulled out of the furnace when the temperature was $400^{\circ} \mathrm{C}$. The weight of each specimen was measured with its crucible at the room temperature of $20 \sim 25^{\circ} \mathrm{C}$. The phase, morphology, and composition of oxide
TABLE 1: List of alloy compositions used in this study.

\begin{tabular}{|c|c|c|c|c|c|c|c|c|c|c|}
\hline mos & 0 & $\mathrm{Cr}$ & Mo & $\mathrm{W}$ & 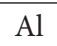 & $\mathrm{Ti}$ & $\mathrm{Ta}$ & C & B & $1 \sqrt{1}$ \\
\hline 1 & 75 & 11.5 & 5 & 0 & & 0 & 5 & 0.1 & 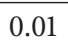 & $\mathrm{Bal}$ \\
\hline & & & & & & & & & 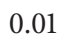 & 1 \\
\hline & 7.5 & & 2.5 & 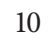 & 3 & 5 & & & 01 & Bal. \\
\hline & 7.5 & & & 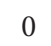 & & 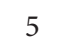 & 5 & & .01 & $\mathrm{Bal}$ \\
\hline M-5 & 0 & .5 & 2.5 & 5 & & 0 & 0 & & 0.01 & Bal. \\
\hline & 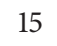 & & & 5 & & & & & & \\
\hline & 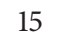 & & & 5 & & c & 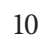 & & & \\
\hline & 0 & & & 5 & & & 10 & & 0.01 & DaI. \\
\hline & 7.5 & 8 & 2.5 & 5 & & & & & 0.01 & $3 \mathrm{al}$ \\
\hline & & 15 & & 5 & & & 0 & & 0.01 & Bal. \\
\hline & 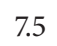 & 15 & 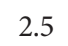 & 5 & & & 10 & & 0.01 & Bal. \\
\hline $4-12$ & 7.5 & 8 & 2 & 5 & & & 10 & & .01 & Bal. \\
\hline M-13 & 0 & 8 & 2.5 & 0 & & & & & 0.01 & Bal. \\
\hline M-14 & 15 & 15 & 2 & 0 & & & 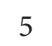 & & 0.01 & $3 a l$. \\
\hline M-15 & 15 & 8 & 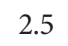 & 10 & & & & & 01 & Bal. \\
\hline 1-16 & 0 & 15 & 2 & 10 & & & 5 & & & $3 \mathrm{al}$ \\
\hline & 7.5 & & 0 & 0 & & & 0 & & & Bal. \\
\hline & & & 5 & 10 & & & & & & Bal. \\
\hline & 5 & & 5 & 0 & & & & & 01 & Bal. \\
\hline & 7.5 & & 0 & 10 & & & & & & Bal. \\
\hline M-21 & 0 & 11.5 & c & 5 & & & 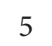 & & 0.01 & Bal. \\
\hline$[-22$ & 15 & & 5 & 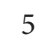 & & & & & & Bal. \\
\hline & 15 & & 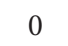 & 5 & & & & & & Bal. \\
\hline-24 & 0 & 11.5 & 5 & 5 & & & 5 & & & Bal. \\
\hline & & 8 & ( & 5 & & & & & & $3 a l$. \\
\hline & & 15 & 5 & $J$ & & & & & & $3 \mathrm{al}$ \\
\hline M-27 & 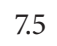 & 15 & c & - & & & 5 & & & Bal. \\
\hline M-28 & 7.5 & 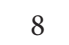 & 5 & 5 & & & & & 01 & Bal. \\
\hline-29 & , & 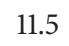 & & 5 & & & & & & Bal. \\
\hline & , & & & - & & & & & & Bal. \\
\hline 31 & 7.5 & 1 & 2 & 5 & & 2 & 5 & & 01 & Bal. \\
\hline & 7 & & 2 & 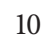 & & & & & & Bal. \\
\hline & & & & 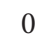 & & & & & & Bal. \\
\hline & 7.5 & & & 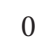 & & & & & & Bal. \\
\hline & & & & & & & & & & Bal. \\
\hline & 15 & 11.5 & 2 & - & & & & & & Bal. \\
\hline 97 & 0 & 1 & 2 & - & & & & & 01 & Bal. \\
\hline o & 0 & 5 & 2 & {[} & & & 1 & & 01 & Bal. \\
\hline & 15 & & & 5 & & & & & & $\mathrm{al}$. \\
\hline & & 15 & & 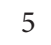 & & & & & & Bal. \\
\hline & 7.5 & 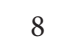 & & 5 & & & & & & Bal. \\
\hline & & 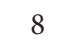 & & & & & & & & Bal. \\
\hline & 7.5 & 15 & & & & & 10 & & & Bal. \\
\hline 44 & 15 & 8 & 2 & 0 & & 2 & - & 0.1 & 01 & Bal. \\
\hline 5 & 0 & 15 & 2 & 0 & & 2.5 & 5 & 0.1 & 1 & Bal. \\
\hline & 0 & 8 & 2.5 & & & 2.5 & . & & & Bal. \\
\hline \pm & 15 & 15 & 2.5 & 10 & & & 5 & & & Bal. \\
\hline & 7.5 & & - & 0 & & & 0 & r & 0.01 & Bal. \\
\hline & 7.5 & & 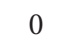 & 10 & & & & & 0.01 & Bal. \\
\hline & 7.5 & & 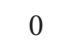 & 0 & & & & & & Bal. \\
\hline RSM-51 & 7.5 & 11.5 & 5 & . & . & 2.5 & 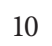 & 0.1 & 0.01 & 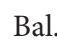 \\
\hline
\end{tabular}


TABle 1: Continued.

\begin{tabular}{lcccccccccc}
\hline Alloys & $\mathrm{Co}$ & $\mathrm{Cr}$ & $\mathrm{Mo}$ & $\mathrm{W}$ & $\mathrm{Al}$ & $\mathrm{Ti}$ & $\mathrm{Ta}$ & $\mathrm{C}$ & $\mathrm{B}$ & $\mathrm{Ni}$ \\
\hline RSM-52 & 15 & 11.5 & 0 & 5 & 3 & 2.5 & 5 & 0.1 & 0.01 & Bal. \\
RSM-53 & 0 & 11.5 & 5 & 5 & 3 & 2.5 & 5 & 0.1 & 0.01 & Bal. \\
RSM-54 & 0 & 11.5 & 0 & 5 & 8 & 2.5 & 5 & 0.1 & 0.01 & Bal. \\
RSM-55 & 15 & 11.5 & 5 & 5 & 8 & 2.5 & 5 & 0.1 & 0.01 & Bal. \\
RSM-56 & 7.5 & 15 & 0 & 5 & 5.5 & 0 & 5 & 0.1 & 0.01 & Bal. \\
RSM-57 & 7.5 & 8 & 5 & 5 & 5.5 & 0 & 5 & 0.1 & 0.01 & Bal. \\
RSM-58 & 7.5 & 8 & 0 & 5 & 5.5 & 5 & 5 & 0.1 & 0.01 & Bal. \\
RSM-59 & 7.5 & 15 & 5 & 5 & 5.5 & 5 & 5 & 0.1 & 0.01 & Bal. \\
RSM-60 & 7.5 & 11.5 & 2.5 & 5 & 5.5 & 2.5 & 5 & 0.1 & 0.01 & Bal. \\
RSM-61 & 7.5 & 11.5 & 2.5 & 5 & 5.5 & 2.5 & 5 & 0.1 & 0.01 & Bal. \\
RSM-62 & 7.5 & 11.5 & 2.5 & 5 & 5.5 & 2.5 & 5 & 0.1 & 0.01 & Bal. \\
\hline
\end{tabular}

scales of selected samples were analyzed by XRD (X-Ray Diffraction), SEM (Scanning Electron Microscopy) equipped with EDS (Energy Dispersive Spectroscopy) after 20 cycles of oxidation tests.

The mass gain after oxidation was statistically analyzed as a response surface model. The mass gain, that is, response, is expressed as a function of content of the seven alloying elements as the following equation [20]:

$$
y=\beta_{0}+\sum_{i=1}^{i=7} \beta_{i} x_{i}+\sum_{i=1}^{i=7} \beta_{i i} x_{i}^{2}+\sum_{i=1}^{i=7} \sum_{j=1}^{j=7} \beta_{i j} x_{i} x_{j},
$$

where $\beta_{0}$ is the response at the center of the experiment, $\beta_{i}$ is the coefficient of main effects, $\beta_{i i}$ is the coefficient of quadratic effects, and $\beta_{i j}$ is the coefficient of linear by linear interaction effect. The coefficients are calculated by a regression analysis with the least squares method. $x_{i}$ is the level of a factor, that is, content of an alloying elements in this study.

\section{Results}

The mass gain of specimens is shown in Figure 1 as a function of oxidation cycles. The weight of the alloy specimens gradually increased and the increasing rate was slowly lowered with cycles, meaning that the oxidation rate of specimens is higher at the initial stage and then gradually decreased. The average mass gain after 20 cycles was $0.32367 \mathrm{mg} / \mathrm{cm}^{2}$, the lowest was $0.14349 \mathrm{mg} / \mathrm{cm}^{2}$ of RSM-2, and the largest was $0.73685 \mathrm{mg} / \mathrm{cm}^{2}$ of RSM- 40 .

The pictures (Figure 2) of the specimens after tests show that oxide scale spalled off in the crucibles and the extent of spallation is depending on each alloy. It is seen that the alloy with high mass gain has much spalled oxide.

The mass gain value after oxidation test was analyzed statistically. Figure 3(a) is the main effect plots for the alloying elements on the mass gain, depicting the averaged effects of a specific element. Co, $\mathrm{Cr} \mathrm{W}$, and Mo appeared to affect the mass gain rarely or very weakly. $\mathrm{Al}$ and $\mathrm{Ta}$ are shown to decrease the mass gain effectively, while Ti increases the mass gain.

The effects of elements are examined in more detail with the interaction plots in Figure 3(b). The interaction plots show the mass gain as a function of the content of a specific element, separately under a given concentration of another element. The slope of the plots varies if an element has interaction with another element. In the Co-Cr interaction plot (the first column at second row in Figure 3(b)), the slope of plots is very small and practically not changed by the content of Cr. Co-Mo, Co-Al, and Co-Ti plots did not propose a meaningful interaction as well. However Co-Ta interaction plot (the first column at the last row in Figure 3(b)) showed that the slope is remarkably decreased by addition of Ta more than 5 wt.\% in the alloy. It means that Co has an effect to increase mass gain by oxidation in an alloy without Ta but this effect is suppressed by Ta.

The mass gain versus $\mathrm{Cr}$ plot showed some disturbance with respect to the content of Co but it is not clear whether it is related to a meaningful effect of Co or merely to an experimental error. $\mathrm{Cr}$ and $\mathrm{W}$ appeared to have interaction in a way that $\mathrm{Cr}$ decreases oxidation rate in alloys without $\mathrm{W}$ but increases oxidation rate with $\mathrm{W}$ more than $5 \mathrm{wt} . \%$. Ti is also suspected to have a weak effect to promote the mass gain increase by high $\mathrm{Cr}$ content. On the contrary, it seems that high concentration of $\mathrm{Al}$ or Ta slightly reduces the mass gain by increasing $\mathrm{Cr}$ content.

The slope of the mass gain versus Mo content plots suggests a possibility of weak interaction of Mo with $\mathrm{Al}$, Ti, and $\mathrm{Ta}$. It seems that $\mathrm{Al}$ or Ti promoted an increase of mass gain with increasing Mo content, while Ta suppresses the effect of Mo.

$\mathrm{W}$ appears to have clear interaction with $\mathrm{Cr}$ and may have weak interactions with $\mathrm{Co}$ and $\mathrm{Ti}$. W reduces mass gain in low Cr (8 wt.\%) alloys but increases mass gain in high Cr (15 wt.\%) alloys. Co may have a similar effect with $\mathrm{Cr}$ while Ti may have the opposite effect.

$\mathrm{Al}$ significantly reduces the mass gain of superalloys and showed strong interaction with $\mathrm{Ti}$ and with $\mathrm{Ta}$ and a weak interaction with Mo. The effect of $\mathrm{Al}$ was stronger with high content of Ti while it was reduced by addition of Mo or Ta.

Ti did not have a significant interaction with other elements but it showed weak interactions with various elements. Ti generally increased mass gain with increasing its content in the alloy, and this effect seems to be a little stronger with high content of $\mathrm{Cr}, \mathrm{Mo}, \mathrm{Al}$, and $\mathrm{Ta}$.

The mass gain decreased by increasing Ta content. This influence appeared stronger when the content of $\mathrm{Co}, \mathrm{Cr}$, Mo, and $\mathrm{W}$ is higher while weaker with higher $\mathrm{Al}$ content.

The degree of influences of alloying elements and its significance were determined by regression analysis. Regression gives a coefficient and a significance probability for every term. The coefficients for a factor represent how strong its effect is. It is considered in RSM that the factor with the significance probability, commonly expressed as $P$ value, lower than the significance level is effective really on the results. The significance level is set as 0.05 , usually [21].

Table 2 shows the regression results. The terms for the content of $\mathrm{Mo}, \mathrm{Al}, \mathrm{Ti}, \mathrm{Ta}, \mathrm{Al} * \mathrm{Al}, \mathrm{Co} * \mathrm{Ta}, \mathrm{Cr} * \mathrm{~W}$, and $\mathrm{Al} * \mathrm{Ta}$ have $P$ less than 0.05 . It means that we can believe the effects of $\mathrm{Mo}, \mathrm{Al}, \mathrm{Ti}$, and $\mathrm{Ta}$ and the interactions between $\mathrm{Al}-\mathrm{Al}, \mathrm{Co}-$ $\mathrm{Ta}, \mathrm{Cr}-\mathrm{W}$, and Al-Ta couples as suggested by Figure 3 or by coefficients in Table 2 with high reliability. Nevertheless, we cannot ignore other terms entirely, because the terms with 

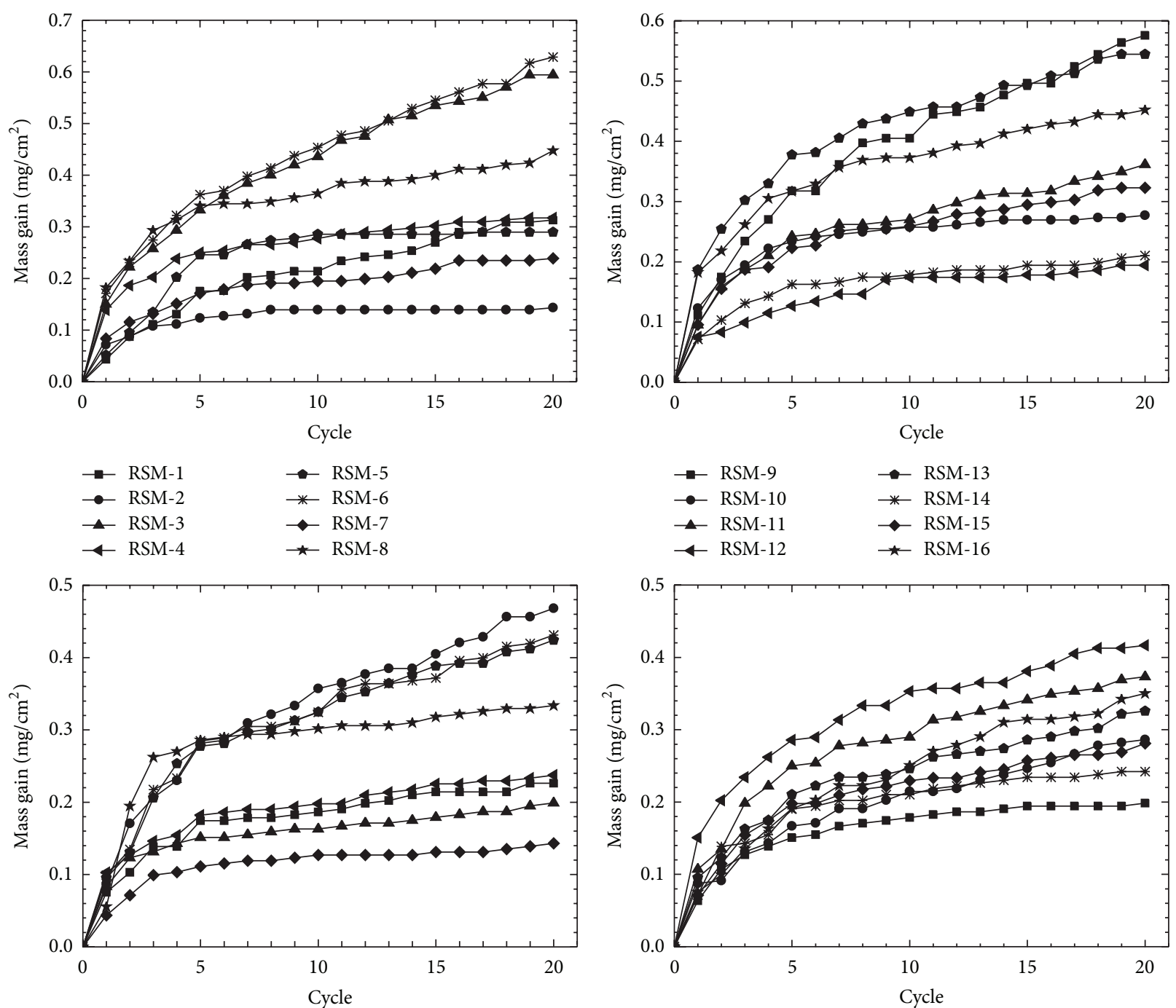
$\rightarrow$ RSM-17
$\rightarrow$ RSM-18
$\longrightarrow$ RSM-21
- RSM-19
* RSM-22
— RSM-20
$\multimap$ RSM-23

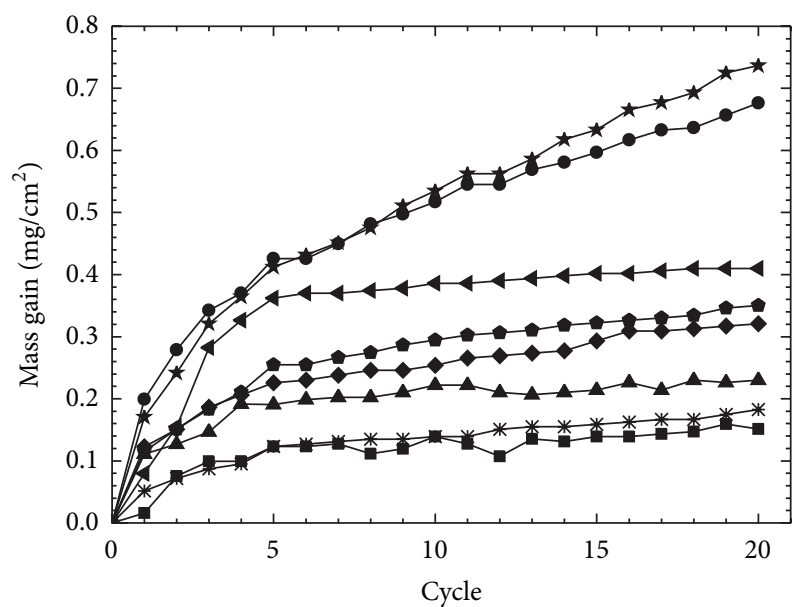
$\rightarrow$ RSM-25
- RSM-26
$\multimap$ RSM-29
- RSM-27
* RSM-30
$\longleftarrow$ RSM-28
$\bullet$ RSM-31

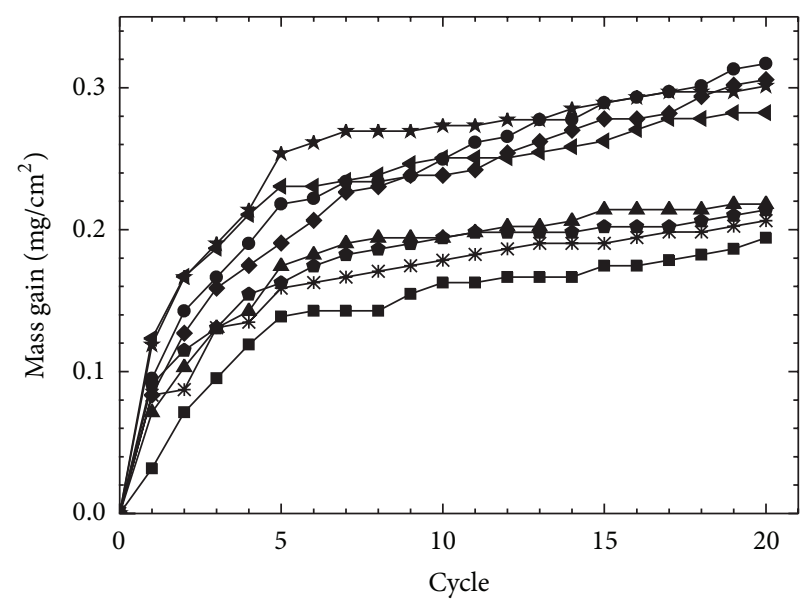

$$
\begin{array}{ll}
\rightarrow \text { RSM-33 } & \rightarrow \text { RSM-37 } \\
\rightarrow \text { RSM-34 } & \rightarrow \text { RSM-38 } \\
- \text { RSM-35 } & - \text { RSM-39 } \\
- \text { RSM-36 } & \text { ٪ RSM-40 }
\end{array}
$$

\begin{tabular}{|c|c|}
\hline- RSM-41 & $\bullet$ RSM-45 \\
\hline$\bullet$ RSM-42 & $*$ RSM-46 \\
\hline$\neg$ RSM-43 & $\multimap$ RSM-47 \\
\hline RSM-44 & * RSM-48 \\
\hline
\end{tabular}



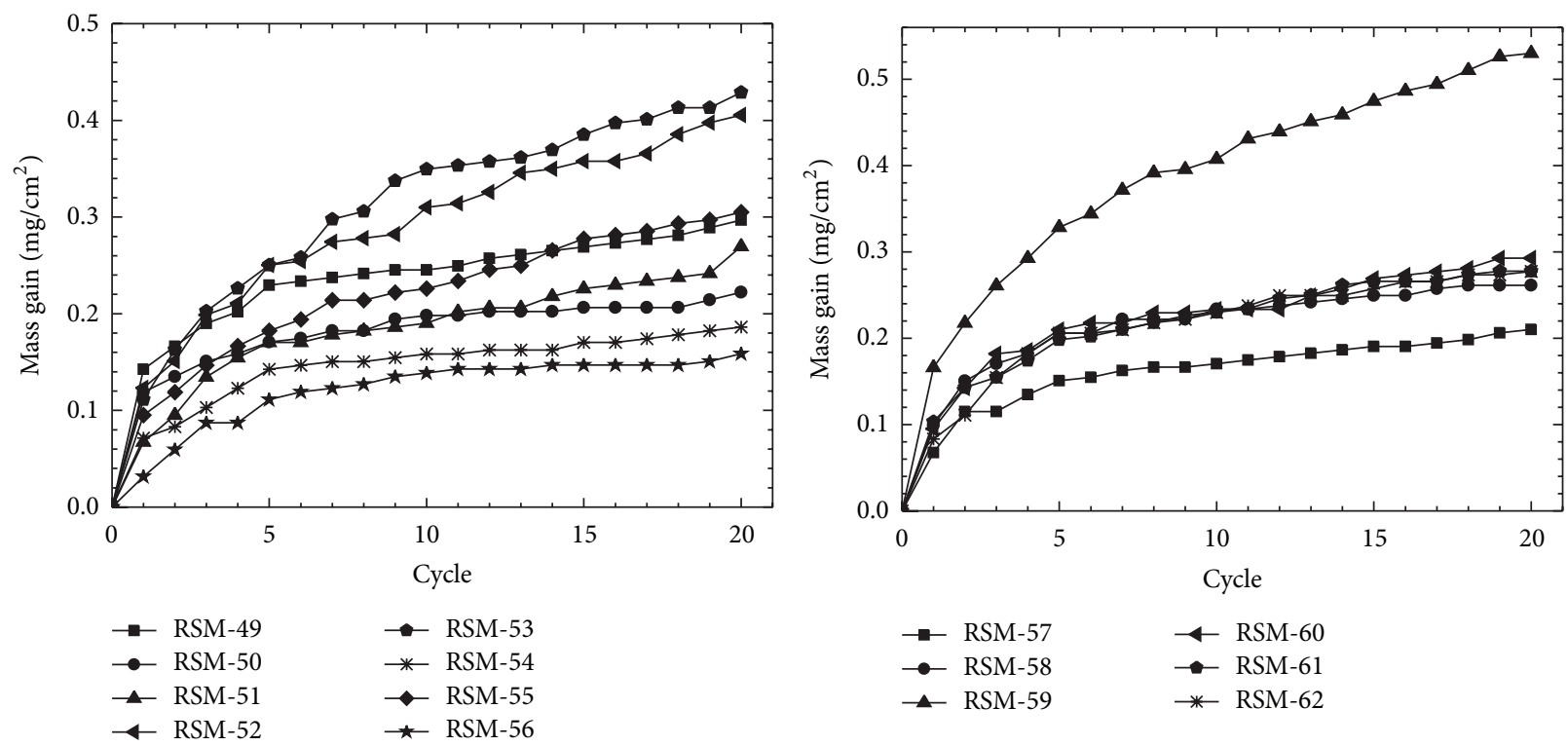

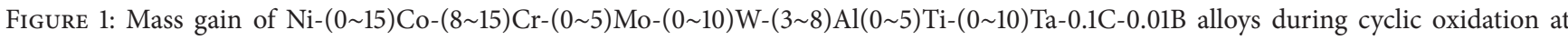
$850^{\circ} \mathrm{C}$.

high $P$ value also have probability, although it is relatively low, of acting as an important factor in the oxidation process.

Among the terms of $P<0.05, \mathrm{Al}$ and $\mathrm{Ta}$ have negative coefficients. The value of their coefficients indicates that $\mathrm{Al}$ is much more effective than Ta to reduce mass gain involved by oxidation. Co also has negative coefficient but it is hardly accepted that Co inhibits oxidation since its coefficient is very small and the $P$ is too large. Mo and Ti are highly probable to increase oxidation rate and the effectiveness of Ti is stronger than that of Mo. Cr and W might promote oxidation slightly but they are relatively less significant, based on the large $P$ values.

Most of the $P$ for quadratic or interaction terms were determined to be larger than 0.05 except for $\mathrm{Al} * \mathrm{Al}, \mathrm{Co} * \mathrm{Ta}$, $\mathrm{Cr} * \mathrm{~W}$, and $\mathrm{Al} * \mathrm{Ta}$. The coefficient of $\mathrm{Al} * \mathrm{Al}$ term is positive and indicates that reducing effect of $\mathrm{Al}$ on the mass gain would be weakened by high Al content. Such a tendency can be confirmed by Figure 3(a) which shows lower negative slope at higher $\mathrm{Al}$ content. The interaction term of Co and $\mathrm{Ta}$ has negative coefficient, meaning that these two elements reinforce the effect of each other to decrease the mass gain. On the contrary, $\mathrm{Cr}$ and $\mathrm{W}$ showed an interaction in a way that one of them increases the mass gain more significantly with an increase of the other element. In the case of $\mathrm{Al}$ and $\mathrm{Ta}$, the interaction suppresses a decrease of mass gain by these elements, as shown by the positive coefficient. Interaction plots for Co-Ta, Cr-W, and Al-Ta couples shown in Figure 3(b) confirm these interactions.

The phase of oxide scales was analyzed by XRD. The diffraction patterns for selected samples are presented in Figure 4 . The alloys with the 1st 3rd, 30th 32nd, and 60th 62 nd highest mass gain were selected to represent the high, moderate, and low oxidation rate, respectively. The XRD pattern showed that the scales were composed mainly of $\mathrm{Cr}_{2} \mathrm{O}_{3}$,
$\mathrm{Al}_{2} \mathrm{O}_{3}, \mathrm{NiCr}_{2} \mathrm{O}_{4}$, and $\mathrm{TiO}_{2}$. A few peaks for $\mathrm{NiO}$ and $\mathrm{CrTaO}_{4}$ were also measured.

The typical cross-sectional views of the oxidized specimens are shown in Figure 5. The composition of the oxide layers was analyzed by EDS. The oxide scale of RSM-40 (Figure 5(a)) is composed mainly of $\mathrm{Cr}_{2} \mathrm{O}_{3}$ layer. $\mathrm{TiO}_{2}$ was observed at the outermost part. Strips (Figure 5(a)) or lumps (Figures 5(b) and 5(c)) of $\mathrm{Al}_{2} \mathrm{O}_{3}$ were developed under the $\mathrm{Cr}_{2} \mathrm{O}_{3}$ layer. Meanwhile, the scales for the group with middlelevel oxidation rate did not have $\mathrm{TiO}_{2}$ and the $\mathrm{Al}_{2} \mathrm{O}_{3}$ layer formed a continuous layer (Figures 5(d) 5(f)). The structure of the scale for the alloys with low oxidation rate was simply composed of a continuous $\mathrm{Al}_{2} \mathrm{O}_{3}$ layer (Figures 5(g) 5(i)).

Some regions showed unsound morphology which is a little deviating from those shown in Figure 5, especially of the alloys with middle or high oxidation rate. Cracks were developed between $\mathrm{TiO}_{2}$ and $\mathrm{Cr}_{2} \mathrm{O}_{3}$ (Figure 6(a)) or between $\mathrm{Cr}_{2} \mathrm{O}_{3}$ and $\mathrm{Al}_{2} \mathrm{O}_{3}$ (Figure 6(b)) for the alloys with high oxidation rate, presumably due to the different thermal expansion coefficients and thermal residual stress. $\mathrm{NiO}$ particle was observed at the outer part of the scale and the $\mathrm{Al}_{2} \mathrm{O}_{3}$ was found at the middle of the scale for a region of RSM-48 (Figure 6(c)). The $\mathrm{Al}_{2} \mathrm{O}_{3}$ was discontinuous for some regions of RSM-60 (Figure 6(d)).

\section{Discussion}

The statistical analysis of the mass gain suggested that $\mathrm{Al}$ and Ta remarkably reduce the oxidation rate, while $\mathrm{Ti}$ promotes oxidation (Figure 3(a) and Table 2). The role of $\mathrm{Cr}$ is not noticed in the main effect plot in Figure 3(a). Co, Mo, and W also did not appear to have significant influences on oxidation. However, Figure 3(b) implies that Co, Cr, Mo, and W affect the mass gain for some cases according to the alloy 


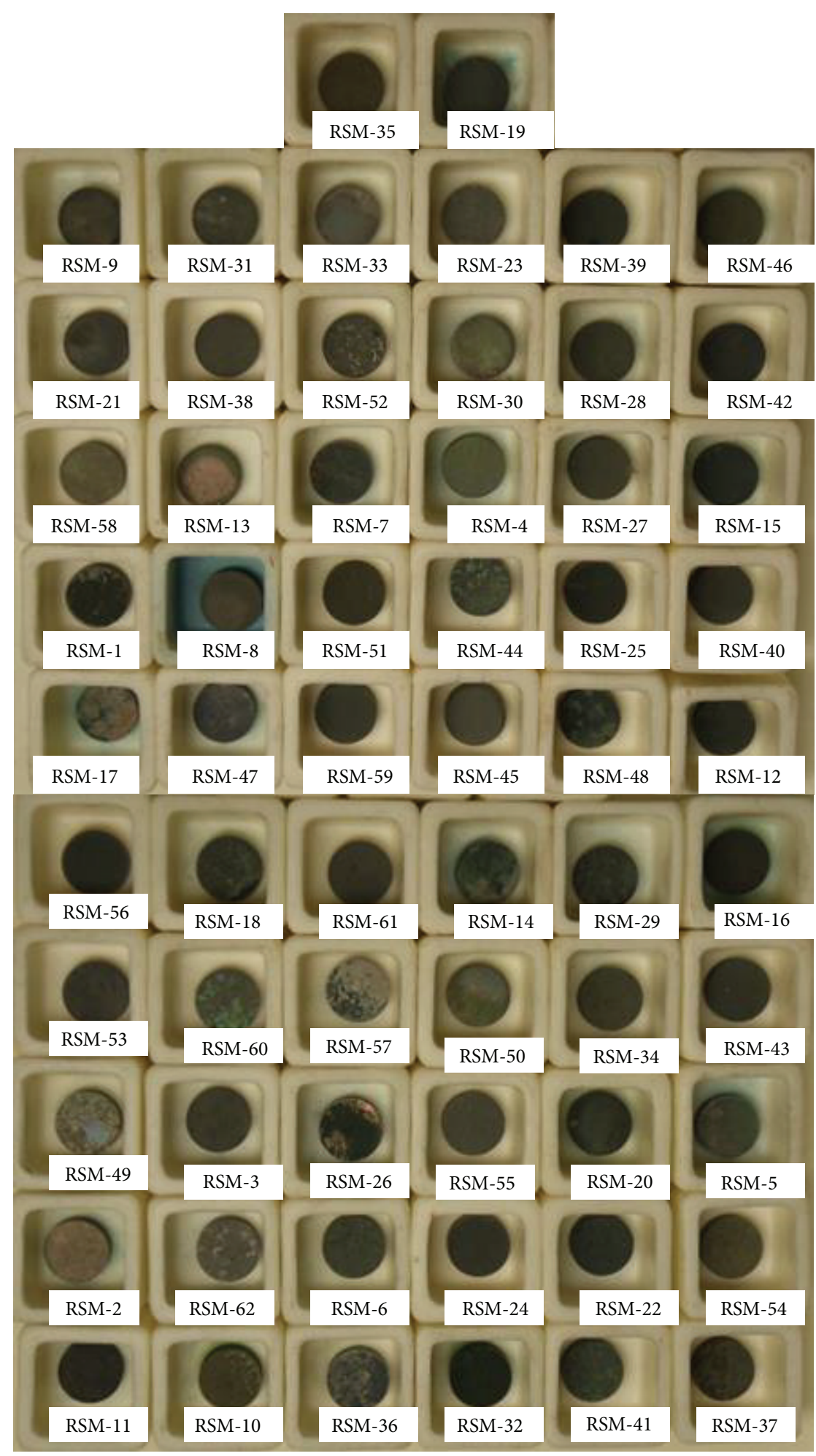

Figure 2: Pictures of Ni-(0 15)Co-(8 15)Cr-(0 5)Mo-(0 10)W-(3 8)Al-(0 5)Ti-(0 10)Ta-0.1C-0.01B alloys after oxidation tests at $850^{\circ} \mathrm{C}$.

composition. It seems that the slope of mass gain versus content of an element of these four is very low after summing up the diverse cases.

Co has strong interaction with $\mathrm{Ta}$, as shown in Figure $3(\mathrm{~b})$, and low $P$ value $(0.030)$ of $\mathrm{Co} * \mathrm{Ta}$ term in
Table 2. Co increased mass gain remarkably for alloys without Ta but changed the mass gain of Ta-containing alloys hardly (Figure 3(b)). CoO in Ni-Co alloy is known to have high concentration of cation vacancy and low activation energy for cation migration [24]. Therefore Co-enriched oxide scale 

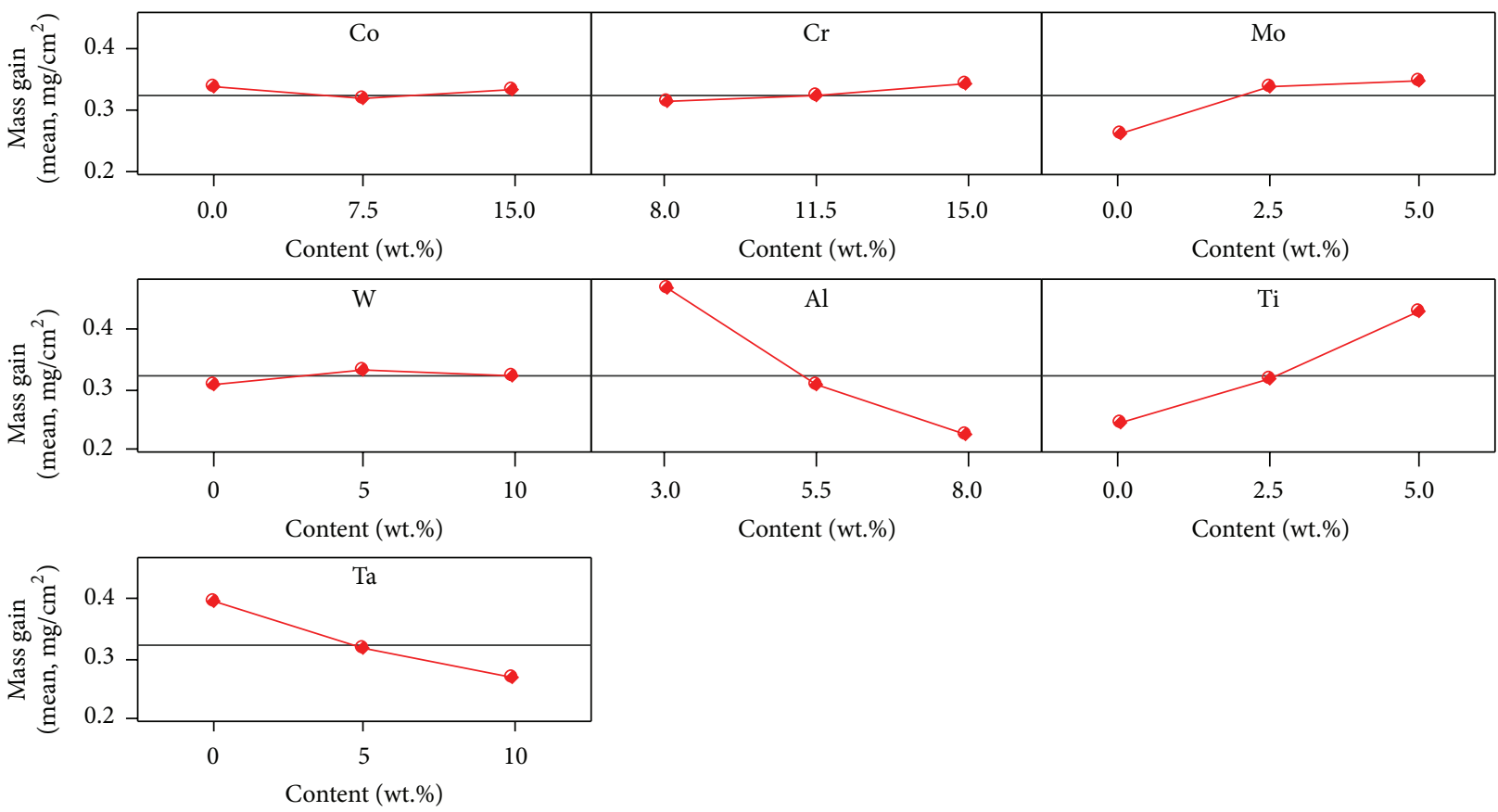

(a)

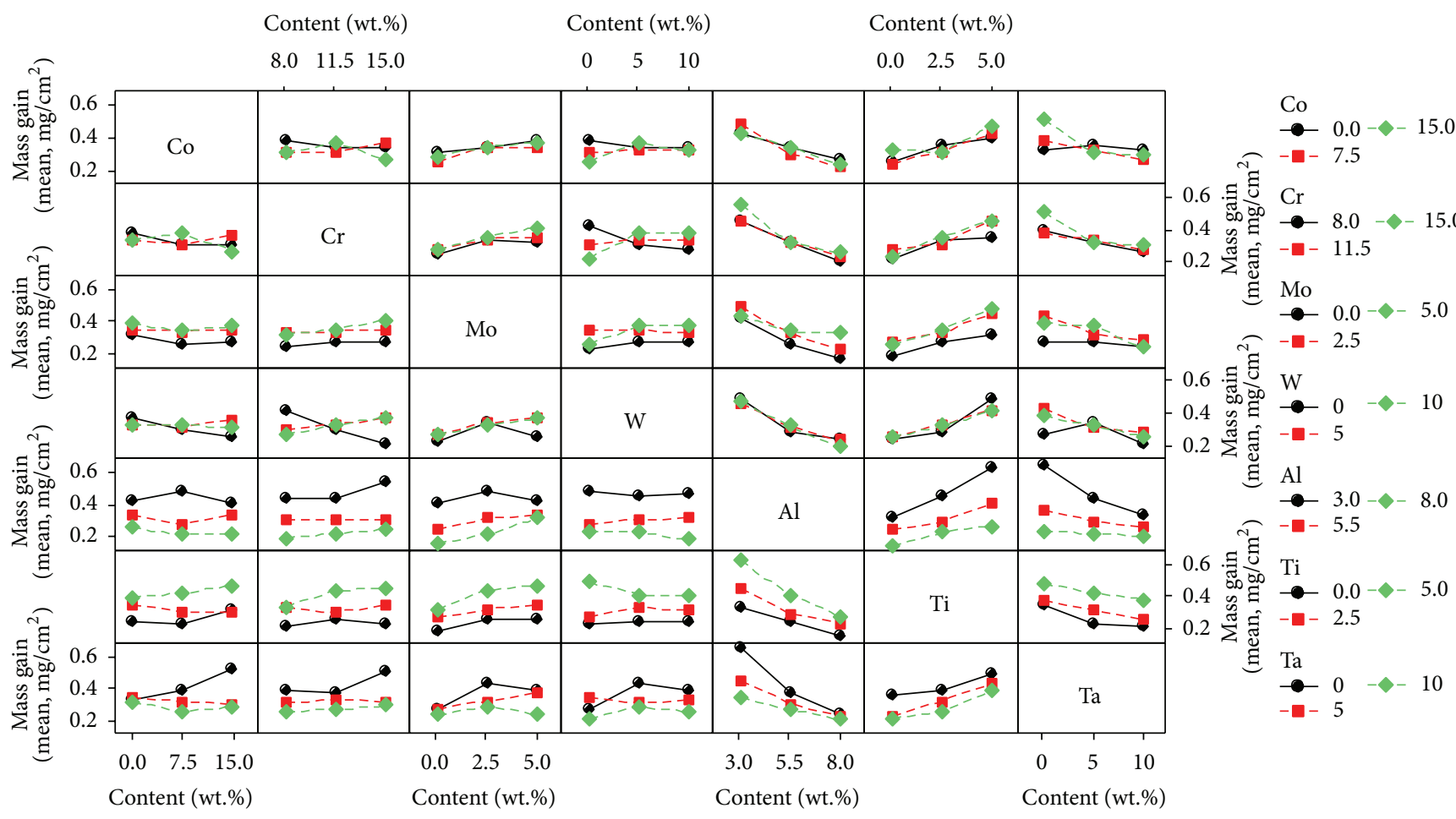

(b)

FIGURE 3: (a) Main effects and (b) interactions of alloying elements on the mass gain by oxidation at $850^{\circ} \mathrm{C}$.

is anticipated to have low protectiveness. However, when $\mathrm{Ta}$ is incorporated in the oxide, the concentration of cation vacancy would be reduced due to the high valence of Ta ion. It seems that 5 wt.\% of Ta is enough to cancel out the effect of Co in the alloys used in this study.
Cr forms a protective $\mathrm{Cr}_{2} \mathrm{O}_{3}$ scale, especially at a temperature lower than about $900^{\circ} \mathrm{C}$. Thus it is expected that high content of $\mathrm{Cr}$ results in low mass gain. Figure 3(b) shows that the beneficial effect of $\mathrm{Cr}$ strongly stands out only in the alloys without W. The $\mathrm{Cr}_{2} \mathrm{O}_{3}$ might be weak because 
TABLE 2: Results of regression analysis for mass gain after oxidation tests $(S=0.07235, R$-square $=87.5 \%$, and $R$-square (adjusted) $=$ $70.7 \%)$.

\begin{tabular}{|c|c|c|c|c|}
\hline Term & Coefficient & SE coefficient & $T$ & $P$ \\
\hline Constant & 1.09641 & 0.398121 & 2.754 & 0.011 \\
\hline Co & -0.00155 & 0.016121 & -0.096 & 0.924 \\
\hline $\mathrm{Cr}$ & -0.03997 & 0.043708 & -0.914 & 0.369 \\
\hline Mo & -0.02271 & 0.048362 & -0.47 & 0.643 \\
\hline $\mathrm{W}$ & -0.04579 & 0.024181 & -1.894 & 0.069 \\
\hline $\mathrm{Al}$ & -0.12666 & 0.053758 & -2.356 & 0.026 \\
\hline $\mathrm{Ti}$ & 0.02162 & 0.048362 & 0.447 & 0.659 \\
\hline $\mathrm{Ta}$ & -0.01862 & 0.024181 & -0.77 & 0.448 \\
\hline $\mathrm{Co} * \mathrm{Co}$ & 0.00048 & 0.00035 & 1.373 & 0.181 \\
\hline $\mathrm{Cr} * \mathrm{Cr}$ & 0.0011 & 0.001608 & 0.687 & 0.498 \\
\hline $\mathrm{Mo} * \mathrm{Mo}$ & -0.00319 & 0.003151 & -1.011 & 0.321 \\
\hline $\mathrm{W} * \mathrm{~W}$ & -0.00024 & 0.000788 & -0.307 & 0.761 \\
\hline $\mathrm{Al} * \mathrm{Al}$ & 0.00677 & 0.003151 & 2.15 & 0.041 \\
\hline $\mathrm{Ti} * \mathrm{Ti}$ & 0.00448 & 0.003151 & 1.422 & 0.167 \\
\hline $\mathrm{Ta} * \mathrm{Ta}$ & 0.00083 & 0.000788 & 1.055 & 0.301 \\
\hline $\mathrm{Co} * \mathrm{Cr}$ & -0.00002 & 0.000974 & -0.021 & 0.983 \\
\hline $\mathrm{Co} * \mathrm{Mo}$ & 0.00024 & 0.001364 & 0.174 & 0.864 \\
\hline $\mathrm{Co} * \mathrm{~W}$ & 0.00079 & 0.000682 & 1.153 & 0.26 \\
\hline $\mathrm{Co} * \mathrm{Al}$ & -0.00037 & 0.001364 & -0.271 & 0.789 \\
\hline $\mathrm{Co} * \mathrm{Ti}$ & -0.00016 & 0.001364 & -0.12 & 0.905 \\
\hline $\mathrm{Co} * \mathrm{Ta}$ & -0.00156 & 0.000682 & -2.293 & 0.03 \\
\hline $\mathrm{Cr} * \mathrm{Mo}$ & 0.00168 & 0.002923 & 0.574 & 0.571 \\
\hline $\mathrm{Cr} * \mathrm{~W}$ & 0.00451 & 0.001462 & 3.086 & 0.005 \\
\hline $\mathrm{Cr} * \mathrm{Al}$ & -0.00141 & 0.002923 & -0.482 & 0.634 \\
\hline $\mathrm{Cr} * \mathrm{Ti}$ & 0.0027 & 0.002923 & 0.924 & 0.364 \\
\hline $\mathrm{Cr} * \mathrm{Ta}$ & -0.00125 & 0.001462 & -0.858 & 0.399 \\
\hline $\mathrm{Mo} * \mathrm{~W}$ & 0.00152 & 0.002046 & 0.741 & 0.465 \\
\hline $\mathrm{Mo} * \mathrm{Al}$ & 0.00558 & 0.004093 & 1.363 & 0.185 \\
\hline $\mathrm{Mo} * \mathrm{Ti}$ & 0.00346 & 0.004093 & 0.845 & 0.406 \\
\hline $\mathrm{Mo} * \mathrm{Ta}$ & -0.00237 & 0.002046 & -1.16 & 0.257 \\
\hline $\mathrm{W} * \mathrm{Al}$ & -0.0005 & 0.002046 & -0.244 & 0.809 \\
\hline $\mathrm{W} * \mathrm{Ti}$ & -0.00199 & 0.002046 & -0.971 & 0.341 \\
\hline $\mathrm{W} * \mathrm{Ta}$ & -0.00076 & 0.001023 & -0.742 & 0.465 \\
\hline $\mathrm{Al} * \mathrm{Ti}$ & -0.0071 & 0.004093 & -1.734 & 0.095 \\
\hline $\mathrm{Al} * \mathrm{Ta}$ & 0.00575 & 0.002046 & 2.808 & 0.009 \\
\hline $\mathrm{Ti} * \mathrm{Ta}$ & 0.00068 & 0.002046 & 0.331 & 0.743 \\
\hline
\end{tabular}

the temperature in this study is close to the temperature by which Cr oxide becomes volatile. In addition, it is known that $\mathrm{W}$ inhibits formation of $\mathrm{Cr}_{2} \mathrm{O}_{3}$ layer $[10,11]$.

Figure 3 shows that Mo slightly increased oxidation rate. However, the slope of mass gain versus Mo content plot becomes nearly zero or negative with low content of W, Al, or Ti. On the contrary, the slope was larger with low Ta content. The interaction coefficients for these terms are larger than 0.05 (Table 2) but it cannot be ignored completely. Many researchers [25-30] reported that Mo is detrimental to oxidation resistance. Mo forms volatile oxide in air. Further, it retards formation of $\mathrm{Cr}_{2} \mathrm{O}_{3}$ and increases possibility of oxide spallation $[10,11]$. It is noted that the above research results

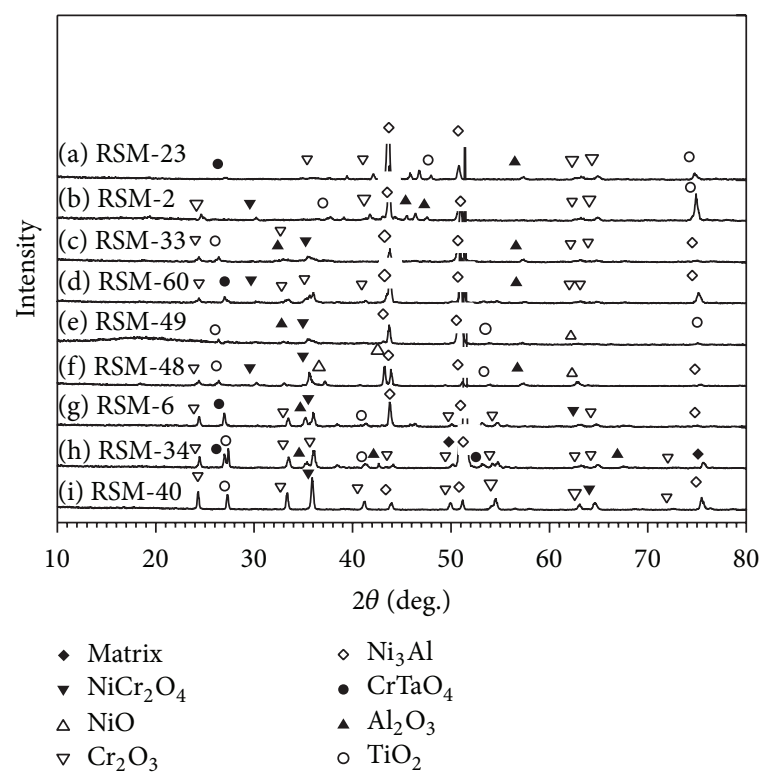

FIGURE 4: X-Ray Diffraction pattern for selected alloys with (a) (c) high, (d) (f) moderate, and (g) (i) low oxidation rate after cyclic oxidation at $850^{\circ} \mathrm{C}$.

are for alloys without Ta. Nevertheless, it is also suggested that formation of $\mathrm{MoO}_{2}$ and $\mathrm{MoO}_{3}$ reduces oxygen activity facilitating selective oxidation of $\mathrm{Cr}$ to form continuous $\mathrm{Cr}_{2} \mathrm{O}_{3}$ layer on $\mathrm{Ni}-\mathrm{Mo}-\mathrm{Cr}$ alloys at $900^{\circ} \mathrm{C}$ [15]. The interaction of Mo with other elements, as shown in Figure 3, may imply that $\mathrm{W}, \mathrm{Al}$, and $\mathrm{Ti}$ increase instability of Mo oxide whereas $\mathrm{Ta}$ stabilizes Mo oxide to some extent.

The coefficient for $\mathrm{W}$ is very small and its $P$ value is large (Table 2), and the slope of mass gain versus $W$ content in the main effect plot (Figure 3(a)) is very low. Therefore, W has a little effect on the oxidation resistance at $850^{\circ} \mathrm{C}$, generally. However, it is noticed that the sign of the slope of mass gain versus $\mathrm{W}$ content plot is reversed by $\mathrm{Cr}$ concentration (Figure 3(b)) and that the $P$ value of the interaction term is lower than the significance level (Table 2). W decreased mass gain of alloys without $\mathrm{Cr}$, meaning that it forms a protective oxide or reduces diffusion of ions through the scale. When $\mathrm{Cr}$ is added to alloy in $15 \mathrm{wt} . \%, \mathrm{~W}$ increases mass gain. $\mathrm{W}^{6+}$ might increase cation vacancy concentration in the Cr-rich oxide which is mainly composed of $\mathrm{Cr}^{3+}$, and hence the diffusion of ions through the oxide layer is facilitated.

$\mathrm{Al}$ is the most important alloying element governing the oxidation resistance. The cross-sectional images in Figure 5 correspond well to the fact that $\mathrm{Al}$ protects the alloy by forming $\mathrm{Al}_{2} \mathrm{O}_{3}$ acting as a barrier layer and it is more protective when the oxide forms a continuous layer than a discontinuous layer [31]. The SEM images shown in Figures 5(a) 5(c) indicate that discontinuous $\mathrm{Al}_{2} \mathrm{O}_{3}$ cannot have high resistance to oxidation. Continuous $\mathrm{Al}_{2} \mathrm{O}_{3}$ layer ensures high oxidation resistance and it provides better protection when the scale is composed solely of $\mathrm{Al}_{2} \mathrm{O}_{3}$ without outer $\mathrm{Cr}_{2} \mathrm{O}_{3}$ layer (Figures $5(\mathrm{~d}) \sim 5(\mathrm{f})$ ) or irregularities (Figures $6(\mathrm{c}) \sim 6(\mathrm{~d})$ ). 


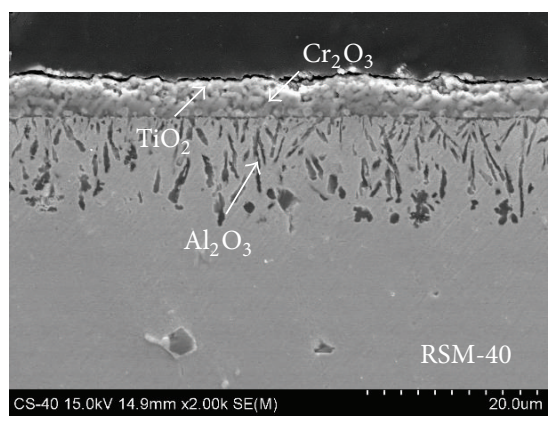

(a)

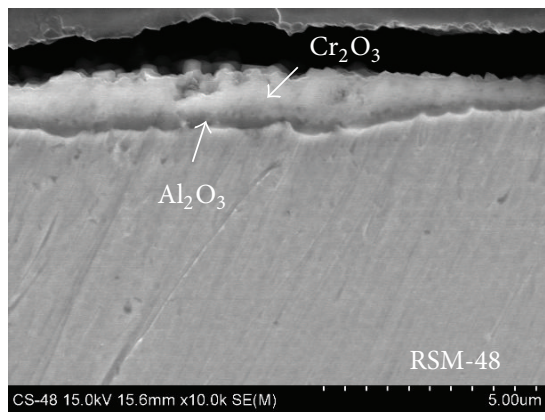

(d)

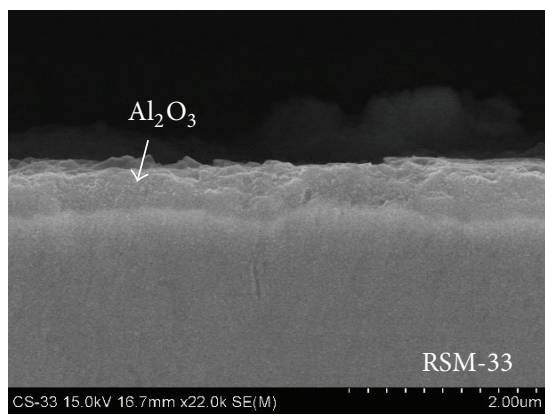

(g)

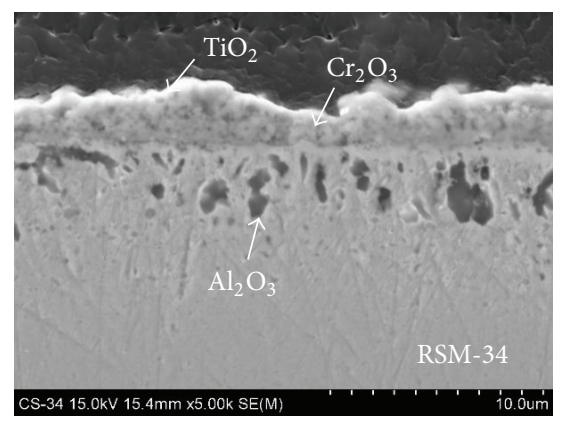

(b)

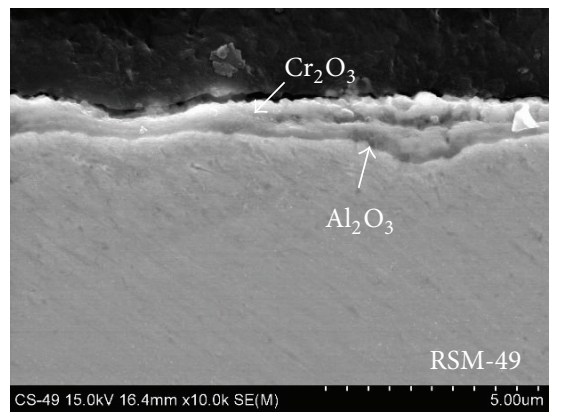

(e)

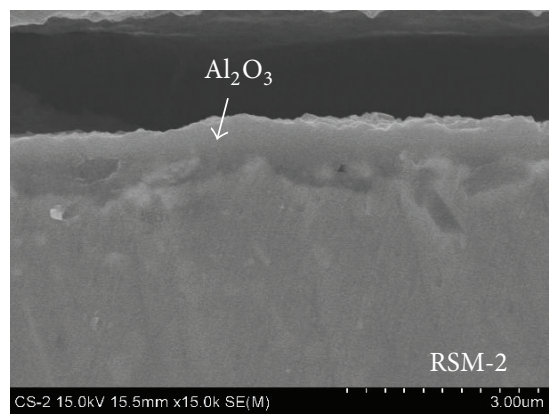

(h)

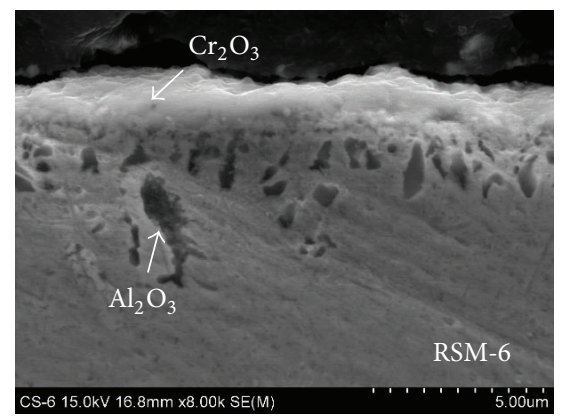

(c)

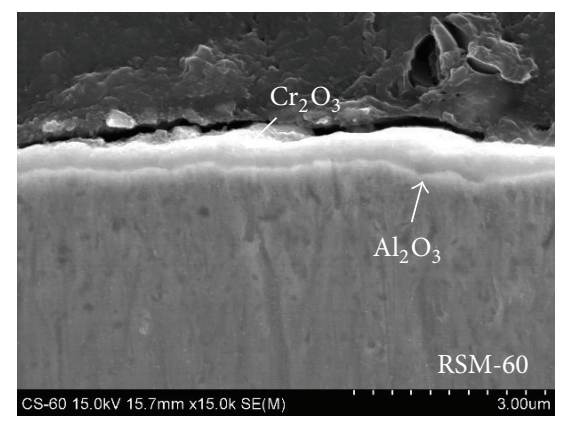

(f)

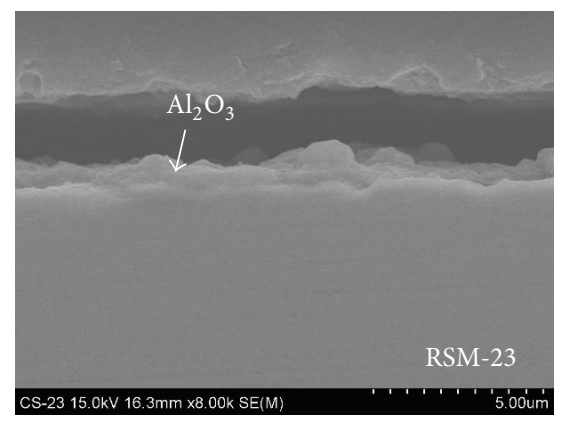

(i)

FIGURE 5: SEM images for the selected alloys with (a) (c) high, (d) (f) moderate, and (g) (i) low oxidation rate after cyclic oxidation at $850^{\circ} \mathrm{C}$.

The morphology of $\mathrm{Al}_{2} \mathrm{O}_{3}$ is dependent on oxygen partial pressure in the gas [32] and concentration of other alloying elements, such as Ta, in the alloy [18]. Thereby the effects of various alloying elements on the oxidation rate can be discussed in a view of their influences on $\mathrm{Al}_{2} \mathrm{O}_{3}$ formation, in addition to their role as a diffusion barrier by themselves. $\mathrm{Ti}$ and $\mathrm{Ta}$ are revealed to have interaction with $\mathrm{Al}$ from Figure 3(b) and Table 2. High concentration of Ti appears to enhance the influence of $\mathrm{Al}$ on the mass gain, whereas $\mathrm{Ta}$ significantly suppresses the effect of Al. The three selected alloys with discontinuous $\mathrm{Al}_{2} \mathrm{O}_{3}$ layer (Figures 5(a) 5(c)) have high Ti content ( $\geq 2.5$ wt. $\%$, two of them have 5 wt.\%) and low Ta content ( $\leq 5 \mathrm{wt} . \%$, two of them have $0 \mathrm{wt} . \%$ ). Contrastively, the three selected images with single layer of continuous $\mathrm{Al}_{2} \mathrm{O}_{3}$ (Figures $5(\mathrm{~g}) \sim 5(\mathrm{i})$ ) are of the alloys with $0 \sim 2.5 \mathrm{wt} . \% \mathrm{Ti}$ (two of them have 0 wt.\%) and $5 \mathrm{wt} . \% \mathrm{Ta}$. The midgroup alloys (Figures 5(d) 5(f)) have $2.5 \mathrm{wt} . \% \mathrm{Ti}$ and $0 \sim$ $5 \mathrm{wt}$. Ta (two of them have $0 \mathrm{wt} . \%$ ).
Ti increases oxidation rate regardless of alloy composition (Figure 3), although the $P$ value for the Ti term is high as 0.659 (Table 2). In addition, $\mathrm{TiO}_{2}$ was found only on the alloys with high oxidation rate (Figures 5(a) and 5(b)). Therefore, Ti can be regarded as harmful to the oxidation resistance with some suspicion. The increasing effect on the mass gain is alleviated by an increase in $\mathrm{Al}$ content (Figure 3(b)). Formation of $\mathrm{TiO}_{2}$ appeared to be impeded in an alloy with high Al content; RSM-6, which has $2.5 \mathrm{wt} . \%$ and $5.5 \mathrm{wt} . \% \mathrm{Al}$, does not have $\mathrm{TiO}_{2}$ layer (Figure 5(c)) on it while RSM-40 has $3 \mathrm{wt} . \% \mathrm{Al}$ and the same concentration of Ti.

$\mathrm{Ta}$ is the element that is believed to have strongest interaction with $\mathrm{Al}$, as proposed by the lowest $P$ value $(0.009)$ of $\mathrm{Al} * \mathrm{Ta}$ term among the interaction terms concerning $\mathrm{Al}$ (Table 2). The positive value $(0.00575)$ of the coefficient for $\mathrm{Al} * \mathrm{Ta}$ term indicates that high Ta concentration weakens the effect of Al to reduce mass gain by an increasing effect which is proportional to $\mathrm{Al}$ content. This proposition is supported 


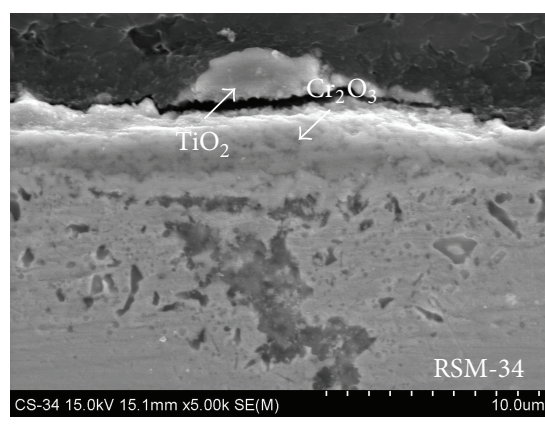

(a)

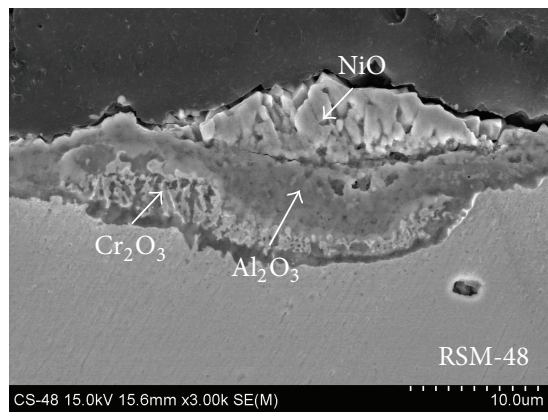

(c)

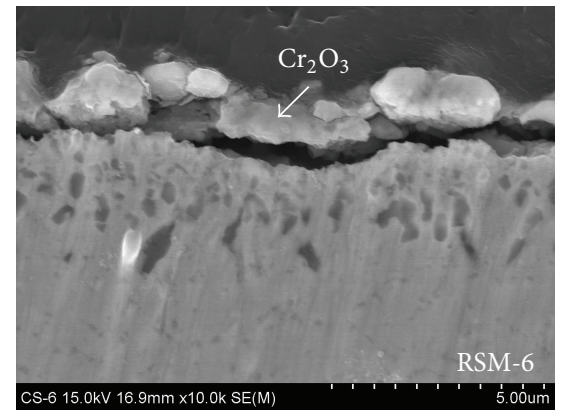

(b)

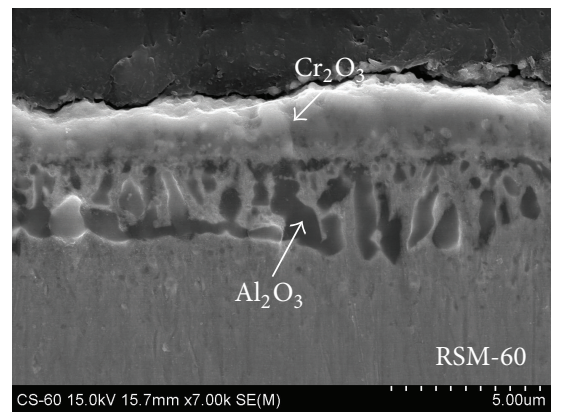

(d)

FiguRE 6: SEM images for (a) RSM-34, (b) RSM-6, (c) RSM-48, and (d) RSM-60 after oxidation at $850^{\circ} \mathrm{C}$, showing local regions of irregularity.

well by previous works reporting that Ta retards formation of $\mathrm{Al}_{2} \mathrm{O}_{3}$ and hence continuous $\mathrm{Al}_{2} \mathrm{O}_{3}$ can be hardly formed with high Ta concentration [33-35].

\section{Conclusions}

The oxidation resistance of Ni-based alloys was evaluated as a function of alloy composition, based on Response Surface Methodology (RSM). The mass gain by cyclic oxidation test at $850^{\circ} \mathrm{C}$ reduced significantly by increasing $\mathrm{Al}$ and Ta content in the alloy but increased with $\mathrm{Ti}$ and Mo content, in average. The main effect of $\mathrm{Co}, \mathrm{Cr}$, and $\mathrm{W}$ on the oxidation rate was very small.

The oxide scale consisted of single continuous layer of $\mathrm{Al}_{2} \mathrm{O}_{3}$ for the alloys with low oxidation rate. Medium Ta content $(5 \mathrm{wt} . \%)$ and low Ti content $(\leq 2.5 \mathrm{wt} . \%)$ are considered to favor formation of protective $\mathrm{Al}_{2} \mathrm{O}_{3}$ scale.

The main effects and interactions of alloying elements on the oxidation rate are found as follows:

(i) $\mathrm{Al}$ is the most effective element to improve oxidation resistance. The degree of effectiveness was enhanced by $\mathrm{Ti}$ and suppressed by $\mathrm{Ta}$.

(ii) Ta has strong interaction with $\mathrm{Al}$, in which Ta weakens the effect of $\mathrm{Al}$ to reduce oxidation rate quantitatively. Ta itself reduces oxidation rate but this effect nearly disappeared when the $\mathrm{Al}$ content is high as 8 wt. $\%$.

(iii) Ti oxide is often found in the scale on the alloys with high oxidation rate and appeared to increase mass gain by oxidation. But the detrimental effect can be reduced by addition of $\mathrm{Al}$.

(iv) Mo slightly increased the oxidation rate but its effect was mitigated by addition of Ta.

(v) Co increased oxidation rate of alloys without Ta. However, it rarely affects the oxidation rate in the alloys with Ta.

(vi) Cr remarkably decreased oxidation rate of alloys without W. In the alloys with $\mathrm{W}, \mathrm{Cr}$ did not exert a significant influence.

(vii) $\mathrm{W}$ reduced oxidation rate of alloys without $\mathrm{Cr}$ but increased oxidation rate of alloys with $15 \mathrm{wt} . \% \mathrm{Cr}$.

\section{Conflict of Interests}

The authors declare that there is no conflict of interests regarding the publication of this paper.

\section{Acknowledgment}

This work was supported by a grant from the Fundamental R\&D Program for Core Technology of Materials (10041233) funded by the Ministry of Trade, Industry and Energy of the Republic of Korea.

\section{References}

[1] C. T. Liu, J. Ma, X. F. Sun, and P. C. Zhao, "Mechanism of the oxidation and degradation of the aluminide coating on 
the nickel-base single-crystal superalloy DD32M," Surface and Coatings Technology, vol. 204, no. 21-22, pp. 3641-3646, 2010.

[2] M. P. Taylor, H. E. Evans, S. Stekovic, and M. C. Hardy, "The oxidation characteristics of the nickel-based superalloy, RR1000, at temperatures of $700-900^{\circ} \mathrm{C}, "$ Materials at High Temperatures, vol. 29, no. 2, pp. 145-150, 2012.

[3] Z. Dong, X. Peng, Y. Guan, L. Li, and F. Wang, "Optimization of composition and structure of electrodeposited $\mathrm{Ni}-\mathrm{Cr}$ composites for increasing the oxidation resistance," Corrosion Science, vol. 62, pp. 147-152, 2012.

[4] D. J. Young, J. Zurek, L. Singheiser, and W. J. Quadakkers, "Temperature dependence of oxide scale formation on high- $\mathrm{Cr}$ ferritic steels in Ar- $\mathrm{H}_{2}-\mathrm{H}_{2} \mathrm{O}$," Corrosion Science, vol. 53, no. 6, pp. 2131-2141, 2011.

[5] Z. Yang, G.-G. Xia, and J. W. Stevenson, "Evaluation of NiCr-base alloys for SOFC interconnect applications," Journal of Power Sources, vol. 160, no. 2, pp. 1104-1110, 2006.

[6] D. Caplan and M. Cohen, "The volatilization of chromium oxide," Journal of The Electrochemical Society, vol. 108, no. 5, pp. 438-442, 1961.

[7] P. Berthod, "Kinetics of high temperature oxidation and chromia volatilization for a binary Ni-Cr alloy," Oxidation of Metals, vol. 64, no. 3-4, pp. 235-252, 2005.

[8] M. J. Donachie and S. J. Donachie, Superalloys: A Technical Guide, The Materials Information Society, Materials Park, Ohio, USA, 2nd edition, 2002.

[9] C. S. Tedmon, "The effect of oxide volatilization on the oxidation kinetics of $\mathrm{Cr}$ and $\mathrm{Fe}-\mathrm{Cr}$ alloys," Journal of the Electrochemical Society, vol. 113, no. 8, pp. 766-768, 1966.

[10] M. E. El-Dahshan, D. P. Whittle, and J. Stringer, "The oxidation of nickel-tungsten alloys," Corrosion Science, vol. 16, no. 2, pp. 83-90, 1976.

[11] S. Espevik, R. A. Rapp, P. L. Daniel, and J. P. Hirth, "Oxidation of Ni-Cr-W ternary alloys," Oxidation of Metals, vol. 14, no. 2, pp. $85-108,1980$.

[12] H. A. Wriedt, "The O-W (oxygen-tungsten) system," Bulletin of Alloy Phase Diagrams, vol. 10, no. 4, pp. 368-384, 1989.

[13] W. W. Webb, J. T. Norton, and C. Wagner, "Oxidation of Tungsten," Journal of The Electrochemical Society, vol. 103, no. 2, pp. 107-111, 1956.

[14] E. A. Gulbransen, "Thermochemistry and the oxidation of refractory metals at high temperature," Corrosion, vol. 26, no. 1, pp. 19-28, 1970.

[15] A. Ul-Hamid, A. I. Mohammed, S. S. Al-Jaroudi, H. M. Tawancy, and N. M. Abbas, "Evolution of oxide scale on a NiMo-Cr alloy at $900^{\circ} \mathrm{C}$," Materials Characterization, vol. 58, no. 1, pp. 13-23, 2007.

[16] X. Huang, J. Li, R. Hu, G. Bai, and H. Fu, "Evolution of oxidation in Ni-Cr-W alloy at $1100^{\circ} \mathrm{C}$," Rare Metal Materials and Engineering, vol. 39, no. 11, pp. 1908-1911, 2010.

[17] S. W. Yang, "Effect of Ti and Ta on the oxidation of a complex superalloy," Oxidation of Metals, vol. 15, no. 5-6, pp. 375-397, 1981.

[18] S.-J. Park, S.-M. Seo, Y.-S. Yoo, H.-W. Jeong, and H. Jang, "Effects of $\mathrm{Al}$ and $\mathrm{Ta}$ on the high temperature oxidation of $\mathrm{Ni}$ based superalloys," Corrosion Science, vol. 90, pp. 305-312, 2015.

[19] H. J. Jang, K. S. Yun, and C.-J. Park, "Analysis of the effects of Ti, $\mathrm{Si}$, and Mo on the resistance to corrosion and oxidation of Fe$18 \mathrm{Cr}$ stainless steels by response surface methodology," Korean Journal of Metals and Materals, vol. 48, no. 8, pp. 741-748, 2010.
[20] D.-C. Yang, I.-S. Jang, M.-H. Jang, C.-N. Park, C.-J. Park, and J. Choi, "Optimization of additive compositions for anode in $\mathrm{Ni}-\mathrm{MH}$ secondary battery using the response surface method," Metals and Materials International, vol. 15, no. 3, pp. 421-425, 2009.

[21] B. Nikrooz and M. Zandrahimi, "Optimization of process variables and corrosion properties of a multi layer silica sol gel coating on AZ91D using the Box-Behnken design," Journal of Sol-Gel Science and Technology, vol. 59, no. 3, pp. 640-649, 2011.

[22] S. Leigh, K. Sezer, L. Li, C. Grafton-Reed, and M. Cuttell, "Statistical analysis of recast formation in laser drilled acute blind holes in CMSX-4 nickel superalloy," The International Journal of Advanced Manufacturing Technology, vol. 43, no. 11-12, pp. 10941105, 2009.

[23] T. A. Kircher, B. G. McMordie, and K. Richards, "Use of experimental designs to evaluate formation of aluminide and platinum aluminide coatings," Surface and Coatings Technology, vol. 108-109, no. 1-3, pp. 24-29, 1998.

[24] M. G. C. Cox, B. McEnaney, and V. D. Scott, "A chemical diffusion model for partitioning of transition elements in oxide scales on alloys," Philosophical Magazine, vol. 26, no. 4, pp. 839851, 1972.

[25] P. Kofstad, High Temperature Corrosion, Elsevier Applied Science, London, UK, 1988.

[26] N. Birks, G. H. Meier, and F. S. Pettit, Introduction to the High Temperature Oxidation of Metals, Cambridge University Press, New York, NY, USA, 2nd edition, 2006.

[27] C.-Y. Bai, "Effects of electrical discharge surface modification of superalloy Haynes 230 with aluminum and molybdenum on oxidation behavior," Corrosion Science, vol. 49, no. 10, pp. 38893904, 2007.

[28] F. A. Khalid, N. Hussain, and K. A. Shahid, "Microstructure and morphology of high temperature oxidation in superalloys," Materials Science and Engineering A, vol. 265, no. 1-2, pp. 87-94, 1999.

[29] N. Hussain, K. A. Shahid, I. H. Khan, and S. Rahman, "Oxidation of high-temperature alloys (superalloys) at elevated temperatures in air: I," Oxidation of Metals, vol. 41, no. 3-4, pp. 251-269, 1994.

[30] Q. Yang, W. Xiong, S. Li, H. Dai, and J. Li, "Characterization of oxide scales to evaluate high temperature oxidation behavior of $\mathrm{Ti}(\mathrm{C}, \mathrm{N})$-based cermets in static air," Journal of Alloys and Compounds, vol. 506, no. 1, pp. 461-467, 2010.

[31] S. Wang, Y. Wu, F. Gesmundo, and Y. Niu, "The effect of Si additions on the high-temperature oxidation of a ternary $\mathrm{Ni}$ $10 \mathrm{Cr}-4 \mathrm{Al}$ alloy in $1 \mathrm{ATM} \mathrm{O}_{2}$ at $900-1000^{\circ} \mathrm{C}$," Oxidation of Metals, vol. 69, no. 5-6, pp. 299-315, 2008.

[32] T. J. Nijdam, L. P. H. Jeurgens, and W. G. Sloof, "Promoting exclusive $\alpha-\mathrm{Al}_{2} \mathrm{O}_{3}$ growth upon high-temperature oxidation of NiCrAl alloys: experiment versus model predictions," Acta Materialia, vol. 53, no. 6, pp. 1643-1653, 2005.

[33] A. Sato, Y.-L. Chiu, and R. C. Reed, "Oxidation of nickel-based single-crystal superalloys for industrial gas turbine applications," Acta Materialia, vol. 59, no. 1, pp. 225-240, 2011.

[34] G. N. Irving, J. Stringer, and D. P. Whittle, "The oxidation of Co$20 \%$ Cr base alloys containing Nb or Ta," Corrosion Science, vol. 15, no. 5, pp. 337-344, 1975.

[35] H. Guo, T. Zhang, S. Wang, and S. Gong, "Effect of Dy on oxide scale adhesion of $\mathrm{NiAl}$ coatings at $1200^{\circ} \mathrm{C}$," Corrosion Science, vol. 53, no. 6, pp. 2228-2232, 2011. 

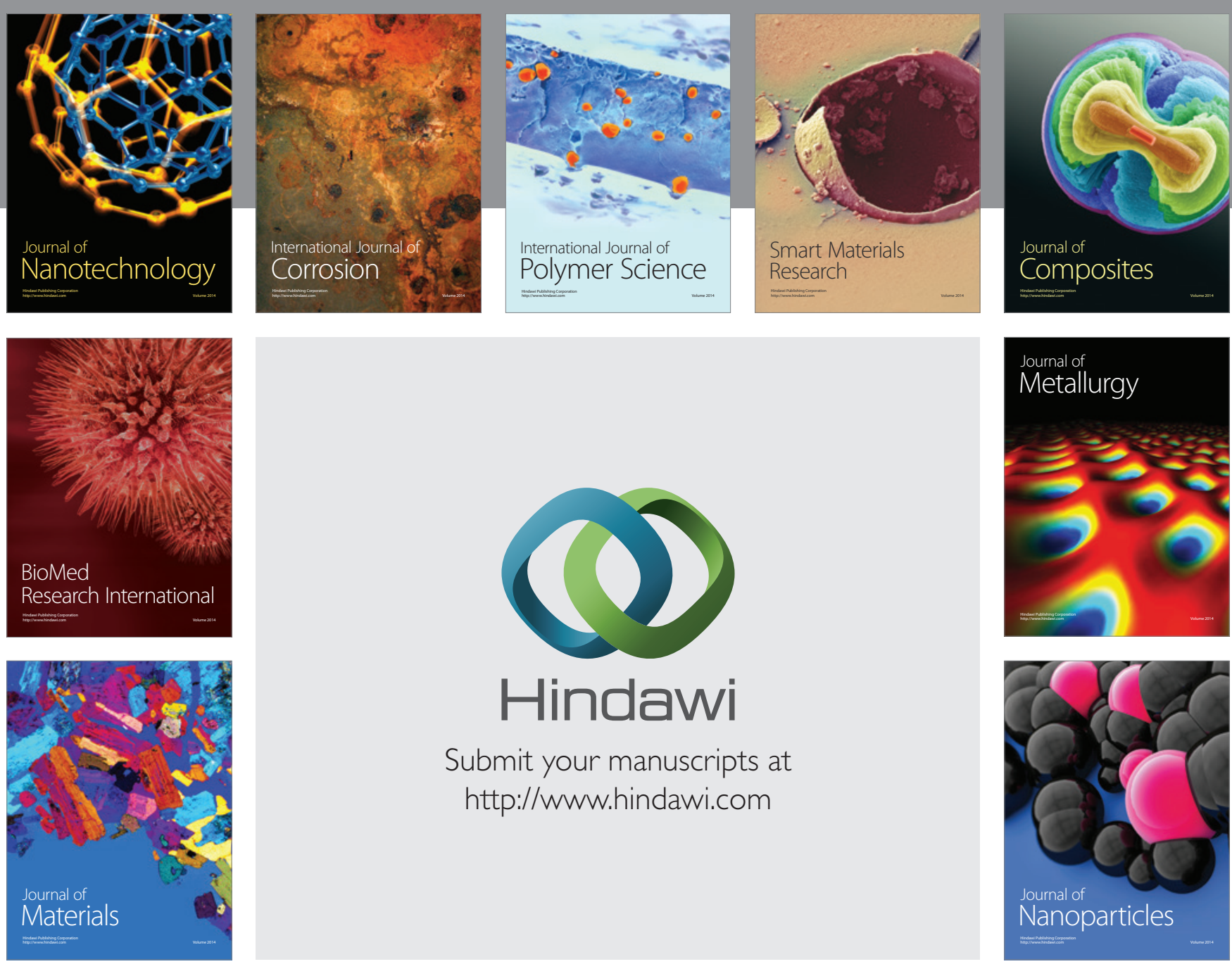

Submit your manuscripts at http://www.hindawi.com
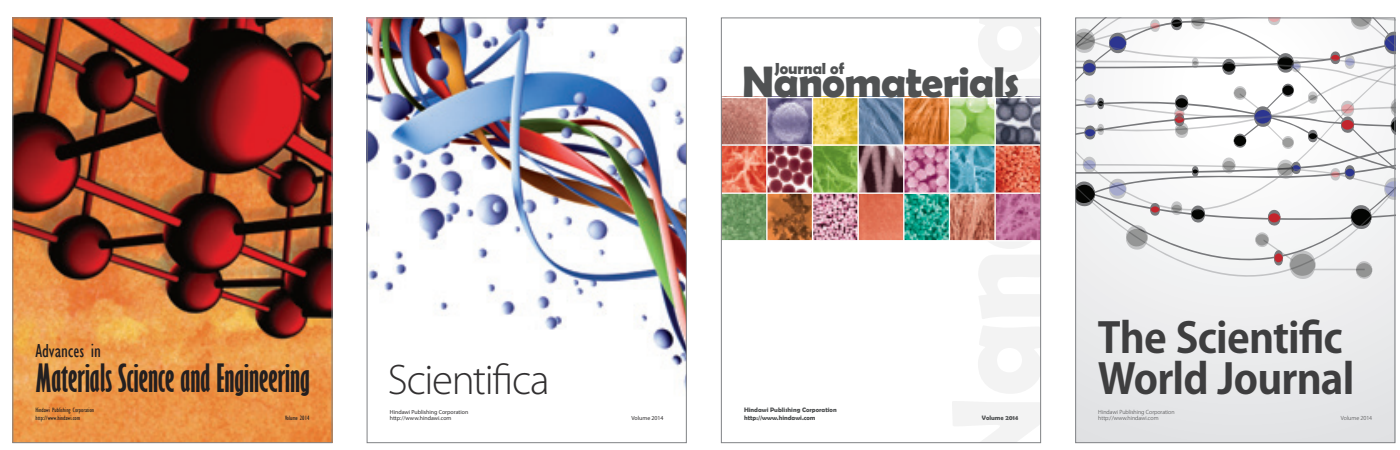

\section{The Scientific World Journal}
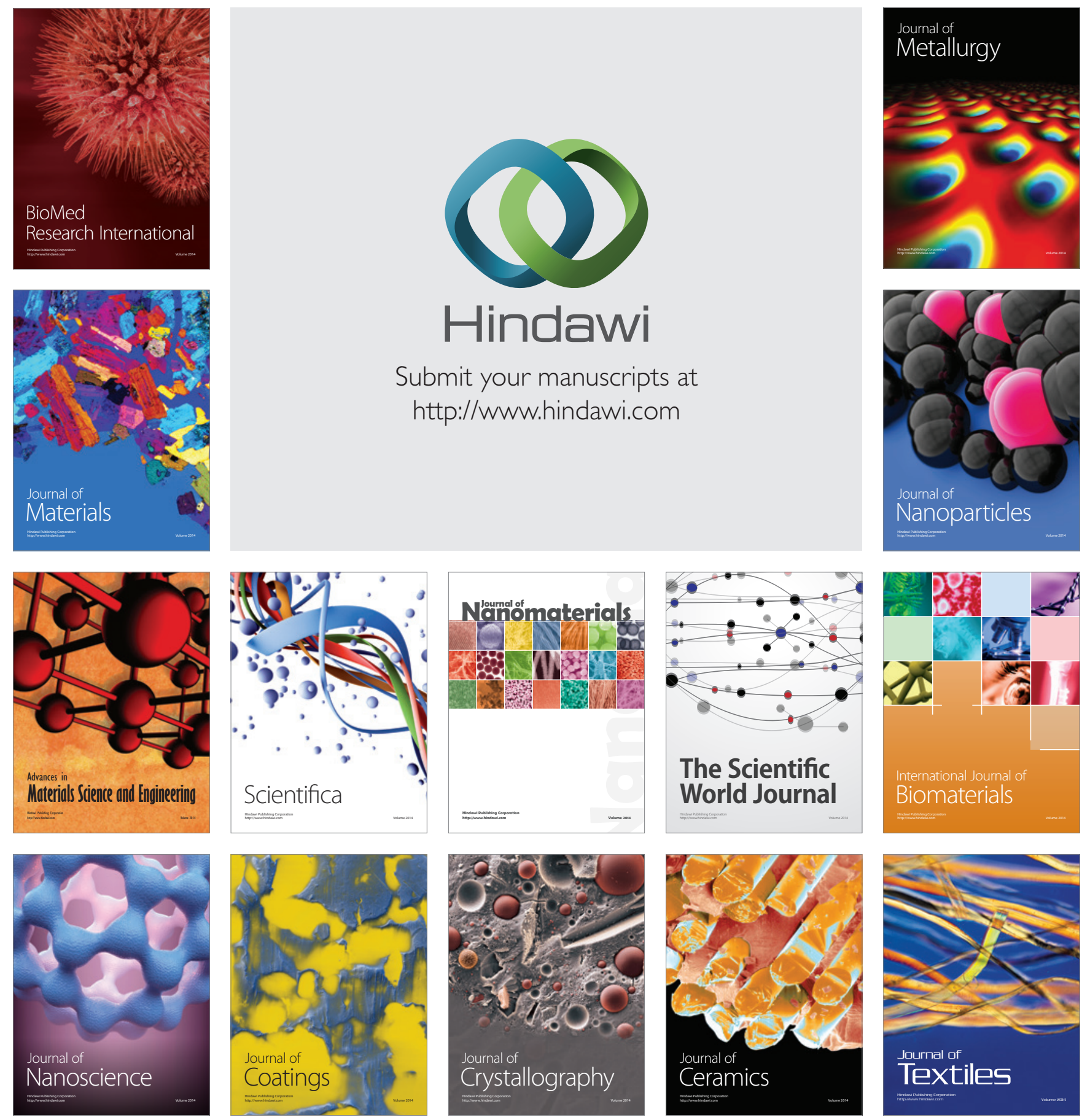